\title{
Purification and some properties of carboxynorspermidine synthase participating in a novel biosynthetic pathway for norspermidine in Vibrio alginolyticus
}

\author{
Hiroshi Nakao, Sumio Shinoda and Shigeo Yamamoto* \\ Faculty of Pharmaceutical Sciences, Okayama University, Tsushima, Okayama 700, Japan
}

(Received 12. February 1991; revised 17 April 1991; accepted 25 April 1991)

\begin{abstract}
Carboxynorspermidine synthase, mediates the nicotinamide-nucleotide-linked reduction of the Schiff base $\mathrm{H}_{2} \mathrm{~N}\left(\mathrm{CH}_{2}\right)_{3} \mathrm{~N}=\mathrm{CHCH}_{2} \mathrm{CH}\left(\mathrm{NH}_{2}\right) \mathrm{COOH}$. This is formed from L-aspartic $\beta$-semialdehyde (ASA) and 1,3diaminopropane (DAP) and is reduced to carboxynorspermidine $\left[\mathrm{H}_{2} \mathrm{~N}\left(\mathrm{CH}_{2}\right)_{3} \mathrm{NH}\left(\mathrm{CH}_{2}\right)_{2} \mathrm{CH}\left(\mathrm{NH}_{2}\right) \mathrm{COOH}\right]$, an intermediate in the novel pathway for norspermidine (NSPD) biosynthesis. The enzyme was purified to apparent homogeneity from Vibrio alginolyticus and characterized. The overall purification was about 1800 -fold over the crude extract, with a yield of $33 \%$. The enzyme displayed an apparent $M_{\mathrm{r}}$ of $93500 \pm 1000$ by gel filtration and $45100 \pm 500$ by SDS-PAGE, indicating that the native form is probably composed of two subunits of similar size. The specific activity of the purified enzyme was $31.0 \mu \mathrm{mol}$ carboxynorspermidine produced min $^{-1}$ (mg protein) ${ }^{-1}$. The enzyme was activated by dithiothreitol, and inhibited by SH-reactive compounds. The pH and temperature optima were $7.25-7.5$ and $37^{\circ} \mathrm{C}$, respectively. The $K_{\mathrm{m}}$ value for the Schiff base was $4.68 \mathrm{mM}$, measured by varying the ASA concentration while keeping the DAP concentration constant. Putrescine was slightly active as a substrate, forming carboxyspermidine (at about $7 \%$ of the rate of DAP), but ethylenediamine, cadaverine and DASA were inert. The $K_{\mathrm{m}}$ value for NADPH was $1.51 \mathrm{mM}$. NADH was a much poorer cofactor than NADPH. When $V$. alginolyticus was grown in the presence of $5 \mathrm{mM}$-NSPD, the specific activity of this enzyme was reduced by $\sim 70 \%$. NSPD also repressed two other enzymes responsible for its biosynthesis, 2,4-diaminobutyrate decarboxylase and carboxynorspermidine decarboxylase.
\end{abstract}

\section{Introduction}

The polyamine distribution patterns of members of the genera Vibrio and Listonella (formally allocated in Vibrio) are unique in that norspermidine (NSPD), a homologue of spermidine (SPD) with two $\mathrm{C}_{3}$ chains, is a major triamine species, whereas putrescine (PUT) and SPD are found only in small amounts under normal growth conditions (Yamamoto et al., 1983, 1991). Experiments using radiolabelled L-aspartic acid have shown that, in some Vibrio species, it is converted to L-aspartic $\beta$ semialdehyde (ASA), which acts as an aminopropyl group donor in NSPD biosynthesis (Yamamoto et al., 1986a):

Abbreviations: DAP, 1,3-diaminopropane; PUT, putrescine; ASA, $\mathrm{L}$-aspartic $\beta$-semialdehyde; NSPD, norspermidine; C-NSPD, carboxynorspermidine; SPD, spermidine; C-SPD, carboxyspermidine; DTT, dithiothreitol; DABA, L-2,4-diaminobutyric acid.
L-Aspartic $\beta$-semialdehyde + 1,3-diaminopropane + $\mathrm{NADPH}+\mathrm{H}^{+} \rightarrow$ Carboxynorspermidine $+\mathrm{NADP}^{+}+$ $\mathrm{H}_{2} \mathrm{O}$

Carboxynorspermidine $\rightarrow$ Norspermidine $+\mathrm{CO}_{2}$

An analogous reaction using PUT as a diamine precursor instead of DAP, has been demonstrated for SPD biosynthesis in certain bacteria (Tait, 1976, 1985) and seedlings of a plant (Srivenugopal \& Adiga, 1980). However, the enzymes responsible have been studied only in crude or partially purified preparations in experiments aimed primarily at delineating the pathway. In these studies, the Schiff base spontaneously or nonenzymically formed between ASA and PUT has been postulated as a possible substrate in an NADPHdependent enzyme reaction.

In our previous study (Nakao et al., 1990), C-NSPD decarboxylase, the pyridoxal phosphate-dependent enzyme that catalyses reaction 2 , was purified from a 
slightly halophilic Vibrio alginolyticus to homogeneity and some of its properties were studied. This paper describes the purification and characterization of the enzyme which catalyses the reductive condensation of ASA with DAP resulting in the synthesis of C-NSPD and $\mathrm{H}_{2} \mathrm{O}$ (reaction 1). The enzyme will be referred to as C-NSPD synthase (ASA-DAP Schiff base reductase, EC 1.5.1.-).

\section{Methods}

Chemicals and materials. $\mathrm{NADP}^{+}, \mathrm{NAD}^{+}$and their reduced forms, were purchased from Oriental Yeast (Japan); allylglycine (D- and L-), bovine albumin (A 4378), dithiothreitol (DTT) and standard marker proteins for SDS-PAGE were from Sigma ; DEAE-Sepharosec CL-6B, Sephacryl S-200 HR and Blue Sepharose CL-6B were from Pharmacia LKB; and hydroxyapatite was from Wako (Japan). ASA and its optical isomer were prepared by ozonolysis of the corresponding forms of allylglycine, purified and stored in $4 \mathrm{M}-\mathrm{HCl}$ at $4{ }^{\circ} \mathrm{C}$ (Black \& Wright, 1955). The yield of ASA has been reported to be $80 \%$ and the amount stated is on the basis of this yield. Before use, a small sample of this solution was adjusted to $\mathrm{pH} \mathrm{6.5-6.7} \mathrm{using} \mathrm{KHCO}_{3}$, with stirring. CNSPD and C-SPD were prepared as previously described (Nakao et al., 1990). Human $\gamma$-globulin $\left(M_{\mathrm{r}}=160000\right)$, BSA (67000) and ovalbumin (45000) from Sigma, and yeast glucose-6-phosphate dehydrogenase $(128000)$ and yeast hexokinase (104000) from Oriental Yeast were used as standard proteins for gel filtration. All other chemicals were of reagent quality.

Bacterial strain and growth conditions. Vibrio alginolyticus ATCC 17749 (type strain) was grown for 6-8 $\mathrm{h}$ as described previously (Nakao et al., 1989), and the cell pellets collected were stored at $-30^{\circ} \mathrm{C}$ until enzyme purification.

Enzyme assay. Enzyme activity was determined by following the formation of C-NSPD from the Schiff base formed between ASA and DAP. The Schiff base was prepared by incubating $175 \mu \mathrm{l} 250 \mathrm{~mm}-$ potassium phosphate buffer, $\mathrm{pH} 7 \cdot 5,50 \mu \mathrm{l} 150 \mathrm{~mm}$-DAP and $50 \mu \mathrm{l}$ $150 \mathrm{~mm}$-ASA at $37^{\circ} \mathrm{C}$ for $5 \mathrm{~min}$. The assay mixture was then adjusted to a final volume of $500 \mu \mathrm{l}$ by adding $50 \mu \mathrm{l}$ bovine albumin solution $\left(30 \mathrm{mg} \mathrm{ml}^{-1}\right), 50 \mu \mathrm{l} 50 \mathrm{~mm}-\mathrm{NADPH}, 50 \mu \mathrm{l} 200 \mathrm{~mm}$-DTT, distilled water and enzyme protein $(0 \cdot 1-100 \mu \mathrm{g})$. After incubation at $37^{\circ} \mathrm{C}$ for $30 \mathrm{~min}$, the reaction was terminated with $0.4 \mathrm{ml} \mathrm{20 \%}(\mathrm{w} / \mathrm{v}) \mathrm{HClO}_{4}$, and the appropriate amount of tryptophan $(25-100 \mathrm{nmol})$ was added as an internal standard. The supernatant after centrifugation at $1500 \mathrm{~g}$ for $10 \mathrm{~min}$ was transferred to a reaction vial for derivatization of C-NSPD formed, followed by $\mathrm{GC}$ analysis with nitrogen-selective detection (Yamamoto et al., 1986a). The identity of C-NSPD was confirmed by GC-MS (Yamamoto et al., 1986a). The reproducibility of the assay method was assessed by calculating the recoveries of known amounts of C-NSPD (10-125 nmol) added to the assay mixtures denatured by the prior addition of $\mathrm{HClO}_{4}$. The recovery for C-NSPD was $94 \pm 5 \%$ $(n=10)$. The formation of C-NSPD was linear with respect to time (10-90 $\mathrm{min}$ ) and the amount of enzyme protein present. The decrease in $A_{340}$ of NADPH was also confirmed with some enzyme preparations, but in these cases the cofactor was reduced to $0.5 \mathrm{~mm}$. One unit of the enzyme was defined as the amount catalysing the formation of $1 \mu \mathrm{mol}$ C-NSPD $\mathrm{min}^{-1}$ under standard assay conditions.

Enzyme purification. Unless otherwise noted, all procedures were done at $2-4{ }^{\circ} \mathrm{C}$, and all dialyses were against 100 vols of the specified buffers for $12 \mathrm{~h}$. A crude estimate of the protein content of column effluents was made by measuring $A_{280}$. For accurate measurement of the protein content of pooled fractions and final enzyme preparation, the Lowry method, or that of Bradford (1976) was used, depending upon the amount of material available.

Frozen cells $(200 \mathrm{~g}$ wet wt) of $V$. alginolyticus were suspended in $800 \mathrm{ml} 20 \mathrm{~mm}$-Tris $/ \mathrm{HCl}, \mathrm{pH} 7 \cdot 5$, containing $1 \mathrm{~mm}$-DTT (buffer A), followed by disruption with an ultrasonic homogenizer in a salt/ice bath. The cell debris was removed by centrifugation at $40000 \mathrm{~g}$ for $30 \mathrm{~min}$, and a small portion of the supernatant (crude extract) was saved for determining the activity after dialysis against two changes of buffer $\mathrm{A}$. The supernatant was fractionated with ammonium sulphate $(50-70 \%)$, and the precipitate was dissolved in a minimum volume of buffer $\mathrm{A}$. After dialysis of this solution against two changes of the same buffer, the precipitate that appeared during dialysis was removed by centrifugation. The clear supernatant $(60 \mathrm{ml})$ was divided into two equal portions, each of which was applied to a DEAE-Sepharose CL$6 \mathrm{~B}$ column $(2.2 \times 25 \mathrm{~cm})$ equilibrated with buffer $\mathrm{A}$. After washing the column with buffer A containing $0.2 \mathrm{M}-\mathrm{NaCl}(300 \mathrm{ml})$, elution was done with a $500 \mathrm{ml}$ linear gradient of $0.2-0.4 \mathrm{M}-\mathrm{NaCl}$ in buffer $\mathrm{A}$ at a flow rate of $15 \mathrm{ml} \mathrm{h}^{-1}$. Active fractions eluting at $0.31-0.33 \mathrm{M}-\mathrm{NaCl}$ were combined $(40 \mathrm{ml})$ and then dialysed against $10 \mathrm{mM}$-potassium phosphate, pH 7.5, containing $1 \mathrm{~mm}$-DTT (buffer B). The dialysed solution was placed on a column $(2.65 \times 20.4 \mathrm{~cm})$ of hydroxyapatite equilibrated with buffer $B$. After washing the column with the same buffer $(330 \mathrm{ml})$, the enzyme was eluted with a $500 \mathrm{ml}$ linear gradient of 10-50 mM-potassium phosphate, $\mathrm{pH} \mathrm{7.5,} \mathrm{at} \mathrm{a} \mathrm{flow} \mathrm{rate} \mathrm{of} 10 \mathrm{ml} \mathrm{h}^{-1}$. Active fractions eluting at 31-38 mM-potassium phosphate were pooled $(100 \mathrm{ml})$ and then dialysed against buffer $\mathrm{B}$. The enzyme solution was applied to a Blue Sepharose CL-6B column $(2 \times 15 \mathrm{~cm})$ equilibrated with buffer $\mathrm{B}$ containing $0.1 \mathrm{M}-\mathrm{NaCl}$, and the column was washed with two column vols of the same buffer. The enzyme was eluted with a $300 \mathrm{ml}$ linear gradient of $0 \cdot 1-1 \mathrm{M}-\mathrm{NaCl}$ at a flow rate of $10 \mathrm{ml} \mathrm{h}^{-1}$. Active fractions eluting at $0.31-0.49 \mathrm{M}-\mathrm{NaCl}$ were pooled $(70 \mathrm{ml})$, and dialysed against buffer A containing $0.02 \% \mathrm{NaN}_{3}$. The dialysed solution was concentrated to about $0.5 \mathrm{ml}$ in an Amicon 8050 ultrafiltration cell with a YM-10 membrane, and subsequently in an Amicon Centricon 30 , and was then stored at $4{ }^{\circ} \mathrm{C}$.

Analytical methods for the purified enzyme. Electrophoresis on a $7.5 \%$ $(\mathrm{w} / \mathrm{v})$ polyacrylamide slab gel under non-denaturing conditions was done as described by Williams \& Reisfeld (1964) except that DTT was added to buffers for gel preparation to give a final concentration of $1 \mathrm{~mm}$. For monitoring the enzyme activity after electrophoresis, the gel was sliced and macerated in buffer $\mathrm{A}$, and left overnight at $4{ }^{\circ} \mathrm{C}$ to elute the enzyme. SDS-PAGE was done in a $10 \%(w / v)$ polyacrylamide slab gel according to Laemmli (1970). Before loading, the enzyme sample was heated for $3 \mathrm{~min}$ with $2 \%(\mathrm{w} / \mathrm{v})$ SDS and $5 \%(\mathrm{w} / \mathrm{v})$ 2-mercaptoethanol in a boiling-water bath. Proteins were visualized by staining with Coomassie Brilliant Blue R-250.

Analytical gel filtration for $M_{\mathrm{r}}$ determination of the native enzyme was done by the use of a Sephacryl S-200 HR column $(2.1 \times 88 \mathrm{~cm})$ calibrated with the standard proteins, as described by Andrews (1965). The column was equilibrated and eluted with $20 \mathrm{~mm}-\mathrm{Tris} / \mathrm{HCl}, \mathrm{pH} 7 \cdot 5$, containing $0.4 \mathrm{M}-\mathrm{NaCl}, 1 \mathrm{mM}$-DTT and $0.02 \% \mathrm{NaN}_{3}$.

Determination of $p I$. A complete loss of enzyme activity was observed upon both isoelectric focusing and chromatofocusing. Therefore, the pI of the purified enzyme was determined by a batchwise method using DEAE-Sepharose CL-6B according to the supplier's instructions. Briefly, $1 \mathrm{ml}$ resin was placed in each of ten $5 \mathrm{ml}$ test tubes, equilibrated with $0.01 \mathrm{M}$-sodium acetate buffer adjusted to $\mathrm{pH} 3.8-4.7$ with $0.1 \mathrm{pH}$ unit increase per tube, and then suspended in $1 \mathrm{ml}$ of the same buffer containing $1 \mathrm{~mm}$-DTT. Into each suspension was stirred $2.5 \mu \mathrm{g}(10 \mu \mathrm{l})$ of the purified enzyme. After stirring for $10 \mathrm{~min}$ at $4{ }^{\circ} \mathrm{C}$, the enzyme activity in the supernatants was measured. 
Table 1. Purification of C-NSPD synthase from $V$. alginolyticus

A typical purification from $200 \mathrm{~g}$ wet wt of cells is shown.

\begin{tabular}{|c|c|c|c|c|c|}
\hline Step & $\begin{array}{l}\text { Total } \\
\text { protein } \\
(\mathrm{mg})\end{array}$ & $\begin{array}{l}\text { Total } \\
\text { activity } \\
\text { (U) }\end{array}$ & $\begin{array}{c}\text { Specific } \\
\text { activity } \\
{\left[\mathrm{U}\left(\mathrm{mg} \mathrm{protein}^{-1}\right]\right.}\end{array}$ & $\begin{array}{l}\text { Purification } \\
\text { (-fold) }\end{array}$ & $\begin{array}{c}\text { Recovery } \\
(\%)\end{array}$ \\
\hline Crude extract & 4445 & $74 \cdot 1$ & 0.0167 & 1 & 100 \\
\hline $50-70 \%$ Ammonium sulphate & 2649 & 71.9 & 0.0271 & $1 \cdot 6$ & 97 \\
\hline DEAE-Sepharose CL-6B & 163 & $101 \cdot 4$ & 0.662 & $37 \cdot 2$ & 137 \\
\hline Hydroxyapatite & $12 \cdot 8$ & $70 \cdot 4$ & $5 \cdot 5$ & $329 \cdot 3$ & 95 \\
\hline Blue Sepharose CL-6B & 0.8 & $24 \cdot 8$ & $31 \cdot 0$ & 1856 & 33 \\
\hline
\end{tabular}

\section{Results}

\section{Establishment of enzyme assay conditions}

Preliminary experiments demonstrated that enzyme activity exhibited an upward curvature with respect to the amount of protein, whenever the components required were added consecutively in an ordinary manner, even if the order of addition was changed. Further, activity decreased in proportion to the concentration of ASA, even when DAP was present in a large excess. These results suggested that the enzyme might be directly inactivated by free ASA. It was also suspected that ASA could react with the $\mathrm{NH}_{2}$ group of the cofactor. To overcome these problems, prior formation of the Schiff base was introduced. However, since it was difficult to measure the absolute yield of the Schiff base formation, we assumed that under the conditions used, the reaction between ASA and DAP runs rapidly to completion, and that there is little chance that both DAP $\mathrm{NH}_{2}$ groups react with ASA. In fact, Schiff base formation, as judged by the amount of C-NSPD formed, reached a maximum within a short period of time $(3 \mathrm{~min})$ and did not change over an incubation of at least $20 \mathrm{~min}$. This may also indicate that the reversibility of the Schiff base reaction was slight. Furthermore, the enzyme appeared to be stabilized by bovine albumin. Enzyme preparations thus stabilized displayed a linear response passing through the origin with respect to the amount of protein and incubation time.

\section{Purification of C-NSPD synthase}

The synthase was a soluble intracellular enzyme. When purified, the final yield of enzyme activity was $33 \%$, with a specific activity of $31.0 \mathrm{U}$ (mg protein) $)^{-1}$ (Table 1$)$, which represented an approximately 1800 -fold purification over the crude extract. DEAE-Sepharose chromatography led to an increase $(36 \%)$ in the total enzyme activity of the crude extract, with a remarkable increase in purification. The increase in the total activity suggests that an enzyme inhibitor(s) may have been removed in the ammonium sulphate fraction. Hydroxyapatite chromatography also resulted in a high improvement in purification with a good yield, but there were still several minor contaminating proteins. The enzyme was further purified with affinity chromatography through a Blue Sepharose column. Unlike C-SPD synthase from Lathyrus sativus seedlings (Srivenugopal \& Adiga, 1980), the $V$. alginolyticus enzyme was so tightly bound to the column that it was not eluted with $5 \mathrm{mM}-\mathrm{NAD}^{+}$or $1-$ 5 mM-NADP ${ }^{+}$. A gradient elution with $\mathrm{NaCl}$ from 0.1 to $1 \mathrm{M}$ dislodged the enzyme and appeared to be highly effective in obtaining the pure enzyme.

\section{Properties of the purified enzyme}

Stability. The final preparation at a protein concentration of about $1.6 \mathrm{mg} \mathrm{ml}^{-1}$ in $20 \mathrm{mM}$-Tris/ $\mathrm{HCl}, \mathrm{pH} 7.5$, containing $1 \mathrm{~mm}$-DTT and $0.02 \% \mathrm{NaN}_{3}$, lost about $15 \%$ of its activity when stored at $4{ }^{\circ} \mathrm{C}$ for a week. Addition of NADPH to this solution gave no significant stabilization of the enzyme. In contrast, DTT, at a concentration (1 mM) much lower than that needed for enzyme activation, had a protective effect on the enzyme during purification and storage. Freezing and thawing of the enzyme resulted in almost complete loss of activity. The enzyme was unstable in buffers of $\mathrm{pH}<6.5$; at $\mathrm{pH} 6.5$, $50 \%$ loss of activity was observed within $12 \mathrm{~h}$ at $4{ }^{\circ} \mathrm{C}$.

Purity and $M_{\mathrm{r}}$ determination. On native PAGE, the purified enzyme migrated as a single species, which coincided with the enzyme activity, and it also gave only one band on SDS-PAGE. On the calibrated column of Sephacryl S-200 HR, the $M_{\mathrm{r}}$ was estimated to be $93500 \pm$ 1000. The $M_{\mathrm{r}}$ corresponding to the SDS-PAGE single band was estimated to be $45100 \pm 500$. Thus, the enzyme appears to consist of two subunits of identical or very similar $M_{\mathrm{r}}$.

Cofactor requirements. The enzyme was completely 
inactive unless NADPH or NADH was added. Plots of enzyme activity as a function of NADPH or NADH concentration displayed typical Michaelis-Menten kinetics and double-reciprocal plots were used to estimate $K_{\mathrm{m}}$ and $V$ values. NADPH gave a $K_{\mathrm{m}}$ of $1.51 \mathrm{mM}$, with a $V$ of $31.0 \mu \mathrm{mol}$ C-NSPD formed $\mathrm{min}^{-1}(\mathrm{mg} \text { protein })^{-1}$, whereas NADH gave a $K_{\mathrm{m}}$ of $2.97 \mathrm{~mm}$, with a $V$ of 13.5 $\mu \mathrm{mol} \mathrm{C-NSPD} \mathrm{formed} \mathrm{min}^{-1}$ (mg protein $)^{-1}$. These data show that the former is the preferred cofactor under the conditions used. Use of DTT became increasingly essential as the protein became purer. Without addition of DTT to the assay mixture, only $7 \%$ of the maximum activity was detected in the purified enzyme. The addition of DTT to the assay mixture, however, greatly activated the enzyme, maximum activation (about 14fold) being observed at $20 \mathrm{~mm}$.

Reversibility of the reaction. Incubation of the purified enzyme in the $\mathrm{pH}$ range $6-8$, with cofactor $\mathrm{NADP}^{+}$or $\mathrm{NAD}^{+}$) concentrations up to $5 \mathrm{mM}$ and substrate (CNSPD) concentrations up to $10 \mathrm{mM}$ produced no observable increase in $A_{340}$ (indicative of C-NSPD oxidation).

Effects of $\mathrm{pH}$ and temperature. Activity was maximal in the range $\mathrm{pH} 7 \cdot 25-7 \cdot 5$, assuming that there was little change in Schiff base formation in the $\mathrm{pH}$ range tested $(6 \cdot 25-8 \cdot 0)$. The alkaline side of the $\mathrm{pH}$ optimum diminished gradually, while the acid side dropped off relatively sharply; $85 \%$ and $18 \%$ of the maximum activity being observed at $\mathrm{pH} 8.0$ and $6 \cdot 25$, respectively. This is mainly due to the instability of the enzyme in acid, as described above. The optimum temperature for enzyme activity in the standard assay was $37{ }^{\circ} \mathrm{C} ; 78 \%$ and $59 \%$ of the maximum activity remained at $30{ }^{\circ} \mathrm{C}$ and $45^{\circ} \mathrm{C}$, respectively, but no activity was observed above $50{ }^{\circ} \mathrm{C}$.

Saturation kinetics and substrate specificity. To determine the kinetics of the enzyme for the ASA-DAP Schiff base, the concentration of ASA was varied from $0 \cdot 25-15 \mathrm{mM}$, while the concentration of DAP was kept at $15 \mathrm{~mm}$. The $K_{\mathrm{m}}$ and $V$ values (determined from Lineweaver-Burk

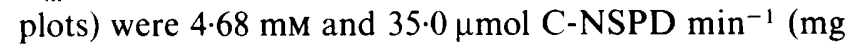
protein $)^{-1}$, respectively.

Substitution of D-ASA for L-ASA resulted in no appearance of the peak corresponding to C-NSPD, suggesting that the enzyme is specific to the Schiff base of the L-form. PUT ( $10 \mathrm{~mm}$ ) as substrate yielded C-SPD at a rate only $7 \%$ of that of DAP. Ethylenediamine, 1,2diaminopropane and cadaverine were totally inactive as judged by $A_{340}$ measurements. When added to the standard assay mixture at a high concentration ( $10 \mathrm{mM})$, these diamines caused $10-20 \%$ inhibition of C-NSPD formation.
Table 2. Effect of addition of NSPD or SPD to growth medium on the specific activities of the enzymes involved in NSPD

$$
\text { biosynthesis }
$$

Growth conditions, preparation of the crude extracts and the assay methods for two decarboxylases are described in the text. Results shown are means of at least two independent experiments. Values in parentheses represent percentages relative to the control.

\begin{tabular}{lccc}
\hline \hline & \multicolumn{2}{c}{ Specific activity [nmol product $\mathrm{h}^{-1}\left(\mathrm{mg}\right.$ protein) ${ }^{-1}$ ] } \\
\cline { 2 - 4 } $\begin{array}{c}\text { Addition to } \\
\text { growth medium }\end{array}$ & $\begin{array}{c}\text { DABA } \\
\text { decarboxylase }\end{array}$ & $\begin{array}{l}\text { C-NSPD } \\
\text { synthase }\end{array}$ & $\begin{array}{c}\text { C-NSPD } \\
\text { decarboxylase }\end{array}$ \\
\hline None & 84 & 873 & 933 \\
NSPD, 5 mM & $21(25)$ & $236(27)$ & $373(40)$ \\
SPD, 5 mM & $33(39)$ & $646(74)$ & $644(69)$ \\
\hline \hline
\end{tabular}

Inhibitors and other properties. Even in the presence of $20 \mathrm{~mm}$-DTT, $5 \mathrm{~mm}$ - $N$-ethylmaleimide and $5 \mathrm{~mm}$-iodoacetamide inhibited enzyme activity by $83 \%$ and $24 \%$, respectively. This, along with stimulation of the enzyme by DTT, indicates that C-NSPD synthase is a sulphhydryl enzyme. Enzyme activity was inhibited $51 \%$ and $10 \%$ by $5 \mathrm{mM}^{-N_{A D P}+}$ and $10 \mathrm{~mm}-\mathrm{NSPD}$, respectively, but $\mathrm{NAD}^{+}$, ATP and SPD were not inhibitory at these concentrations. $\mathrm{Na}^{+}$and $\mathrm{K}^{+}$at $1 \mathrm{M}$ concentration had no effect on enzyme activity. There was no evidence for activity being dependent on metal cations such as $\mathrm{Ca}^{2+}$, $\mathrm{Mg}^{2+}, \mathrm{Fe}^{3+}, \mathrm{Fe}^{2+}, \mathrm{Cu}^{+}, \mathrm{Cu}^{2+}, \mathrm{Mn}^{2+}$ and $\mathrm{Zn}^{2+}$, and these cations were not inhibitory. EDTA (1 mM) showed no significant stimulatory or inhibitory effect on enzyme activity. The pI of the enzyme was judged to be $4 \cdot 2-4 \cdot 3$ since it released from Sepharose CL-6B at this $\mathrm{pH}$ range.

\section{Effect of addition of NSPD to growth medium on the activities of the enzymes involved in its biosynthesis}

To determine whether exogenous NSPD would affect the expression of NSPD biosynthetic enzymes, the organism was grown in the absence (control) or presence of $5 \mathrm{~mm}$ NSPD, and the specific activities of DABA decarboxylase, C-NSPD synthase and C-NSPD decarboxylase were measured in the crude extracts. For comparison, SPD was also examined. The organism was grown for $6 \mathrm{~h}$ in $200 \mathrm{ml}$ synthetic medium containing $0.5 \% \mathrm{NaCl}$ (Yamamoto et al., 1983), and all crude extracts, including the control, were prepared in $20 \mathrm{~mm}$-Tris $/ \mathrm{HCl}, \mathrm{pH} 7.5$, containing $1 \mathrm{mM}$-DTT and $0 \cdot 1 \mathrm{~mm}$-EDTA, then dialysed for $12 \mathrm{~h}$ against two changes of the same buffer containing $0.5 \mathrm{M}-\mathrm{NaCl}$. The inclusion of $\mathrm{NaCl}$ in the dialysis buffer was effective in almost completely removing exogenous NSPD or SPD. The activities of the two decarboxylases were assayed as previously described 
(Nakao et al., 1989, 1990). As shown in Table 2, addition of NSPD significantly decreased the specific activity in all enzymes, compared with the control. Interestingly, SPD also showed a repressive effect on these enzymes, but to a lesser extent than NSPD. The above findings were not the result of an inhibition of stimulation of the bacterial growth, since the cultures grown in the presence of NSPD or SPD showed no significant difference in total cellular protein compared with the control.

\section{Discussion}

Under normal growth conditions, DAP was first detected in cells $2-5 \mathrm{~h}$ (the period of rapid growth) after inoculation. This appearance of DAP coincided with enhanced production of NSPD, the end product in this pathway (Yamamoto et al., 1986b). The enzyme which decarboxylates L-DABA to DAP has previously been purified (Nakao et al., 1989) and the biosynthetic pathway for L-DABA in $V$. alginolyticus is currently under investigation. On the other hand, appreciable incorporation of the radiolabel from $\mathrm{L}-\left[{ }^{14} \mathrm{C}\right]$ aspartic acid into NSPD demonstrates that this bacterium can produce ASA from L-aspartic acid (Yamamoto et al., $1986 a$ ). Thus, the present study was initiated to purify and characterize the enzyme which catalyses the reductive condensation of ASA and DAP to give CNSPD, as an intermediate of NSPD biosynthesis. However, the enzyme was inhibited whenever it was incubated with free ASA, as has been reported for Escherichia coli aspartase (EC 4.3.1.1) (Yumoto et al., 1982). In this study, prior formation of the Schiff base was therefore adopted to facilitate purification of the enzyme. This inhibition by free ASA was probably due to its modification of the $\varepsilon-\mathrm{NH}_{2}$ group of lysine and/or the $\mathrm{SH}$ group of cysteine near to, or in, the active site of the enzyme. Therefore, it is conceivable that, when ASA is being formed from L-aspartic acid in cells, the aldehyde is kept in a masked state to prevent interaction with the synthase. Once the Schiff base is formed with DAP, it will be accepted by C-NSPD synthase.

The highly effective activation by DTT is a distinctive feature of this enzyme. The DTT-requirement and the optimal $\mathrm{pH}$ are similar to those of C-SPD synthase, an analogous enzyme which has been partially purified (50fold) from $L$. sativus (Srivenugopal \& Adiga, 1980). While C-SPD synthases from this plant and from Micrococcus denitrificans and Rhodopseudomonas spheroides (Tait, 1976) can utilize only NADPH as a cofactor, the purified C-NSPD synthase from $V$. alginolyticus can utilize NADH in addition to NADPH, although it shows a marked preference for the latter. Furthermore, the $L$. sativus C-SPD synthase utilizes DAP with only $30 \%$ efficiency of PUT, at an equivalent concentration, indicating that the enzymes clearly differ in substrate specificity. The purified C-NSPD synthase did not catalyse the oxidative cleavage of C-NSPD to ASA and DAP (reverse reaction) under the conditions examined, whether $\mathrm{NADP}^{+}$or $\mathrm{NAD}^{+}$was used as a cofactor.

Previously, C-NSPD decarboxylase has been shown to act on C-SPD at a rate comparable with that of C-NSPD to produce SPD (Nakao et al., 1990). Yet the cellular content of SPD, when the bacterium is grown in a defined medium free from SPD, is less than one-tenth that of NSPD at any growth phase (Yamamoto et al., $1986 b$ ). However, the present study indicated that CNSPD synthase was far more active with the Schiff base formed between DAP and ASA than with that between PUT and ASA. Moreover, formation of SPD in this bacterium can reasonably be attributed to two enzymes responsible for NSPD biosynthesis, as the activity of the classical aminopropyltransferase (EC 2.5.1.16), which utilizes decarboxylated $S$-adenosylmethionine as an aminopropyl donor to give SPD, could not be detected in cell extracts.

Microbial enzymes involved in the conventional route for polyamine biosynthesis are under regulatory control by end products such as SPD (Tabor \& Tabor, 1985). This may also be true of the $V$. alginolyticus enzymes. The reduction in specific activity of all three enzymes involved in NSPD biosynthesis when NSPD is added to the growth medium, indicates its physiological importance in this bacterium. The repression of NSPD biosynthetic enzymes by SPD is suggested by the observation that its presence in the growth medium causes a significant decrease in the cellular concentration of NSPD in Vibrio species (Yamamoto et al., 1991). However, whether there is an actual decrease in the amount of enzyme protein (i.e., repression of enzyme synthesis) or whether there is an induction of modulator(s) such as antizymes (Panagiotidis \& Canellakis, 1984), which can inactivate these enzymes, is unknown.

We are indebted to $\mathrm{Mr} \mathrm{A}$. Iwadoh for performing GC-MS analyses This work was supported in part by a General Grant-in-Aid for Scientific Research from the Ministry of Education, Science, and Culture of Japan.

\section{References}

ANDREws, P. (1965). The gel-filtration behaviour of proteins related to their molecular weights over a wide range. Biochemical Journal 96, 595-606.

BlaCK, S. \& Wright, N. G. (1955). Aspartic $\beta$-semialdehyde dehydrogenase and aspartic $\beta$-semialdehyde. Journal of Biological Chemistry 213, 39-50.

BRADFORD, M. M. (1976). A rapid and sensitive method for the quantitation of microgram quantities of protein utilizing the principle of protein-dye binding. Analytical Biochemistry 72, 248254. 
LAEMmLI, U. K. (1970). Cleavage of structural proteins during the assembly of the head of bacteriophage T4. Nature, London 227, 680685.

NaKaO, H., IshiI, M., Shinoda, S. \& Yamamoto, S. (1989). Purification and some properties of a novel L-2,4-diaminobutyric acid decarboxylase from Vibrio alginolyticus. Journal of General Microbiology 135, 345-351.

Nakao, H., Shinoda, S. \& Yamamoto, S. (1990). Purification and properties of carboxynorspermidine decarboxylase, a novel enzyme involved in norspermidine biosynthesis, from Vibrio alginolyticus. Journal of General Microbiology 136, 1699-1704.

Panagiotidis, C. A. \& Canellakis, E. S. (1984). Comparison of the basic Escherichia coli antizyme 1 and antizyme 2 with the ribosomal proteins S20/L26 and L34. Journal of Biological Chemistry 259, $15025-15027$.

Srivenugopal, K. S. \& Adiga, P. R. (1980). Coexistence of two pathways of spermidine biosynthesis in Lathyrus sativus seedlings. FEBS Letters 112, 260-264.

TABOR, C. W. \& TABOR, H. (1985). Polyamines in microorganisms. Microbiological Reviews 49, 81-99.

TAIT, G. H. (1976). A new pathway for the biosynthesis of spermidine. Biochemical Society Transactions 4, 610-612.

TAIT, G. H. (1985). Bacterial polyamines, structures and biosynthesis. Biochemical Society Transactions 13, 316-318.
Williams, D. E. \& Reisfeld, R. A. (1964). Disc electrophoresis in polyacrylamide gels: extension to new conditions of $\mathrm{pH}$ and buffer. Annals of the New York Academy of Sciences 121, 373-381.

Yamamoto, S., Shinoda, S., Kawaguchi, M., Wakamatsu, K. \& MaKITA, M. (1983). Polyamine distribution in Vibrionaceae: norspermidine as a general constituent of Vibrio species. Canadian Journal of Microbiology 29, 724-728.

Yamamoto, S., Hamanaka, K., Suemoto, Y., One, B. \& Shinoda, S. (1986a). Evidence for the presence of a novel biosynthetic pathway for norspermidine in Vibrio. Canadian Journal of Microbiology 32, 99103.

Yamamoto, S., Yoshida, M., Nakao, H., Koyama, M., Hashimoto, Y. \& SHINODA, S. $(1986 b)$. Variations in cellular polyamine compositions and contents of Vibrio species during growth in media with various $\mathrm{NaCl}$ concentrations. Chemical and Pharmaceutical Bulletin 34, 3038-3042.

Yamamoto, S., Chowdhury, M. A. R., Kuroda, M., Nakano, T., Koumoto, Y. \& ShINODA, S. (1991). Further study on polyamine composition in Vibrionaceae. Canadian Journal of Microbiology 37, 148-153.

Yumoto, N., OKada, M. \& Tokushige, M. (1982). Biospecific inactivation by L-aspartic- $\beta$-semialdehyde. Biochemical and Biophysical Research Communications 104, 859-866. 